\title{
Palaeogeomorphology and its control on the development of sequence stratigraphy and depositional systems of the Early Silurian in the Tarim Basin
}

\author{
Liu Jingyan', Lin Changsong ${ }^{1 *}$, Cai Zhenzhong², Zhu Yongfeng², Yang \\ Yongheng', Peng Li' ${ }^{1}$, Si Baoling ${ }^{1}$, Huang Zhen ${ }^{1}$, Li Huanpu ${ }^{1}$, Xu Yingcai ${ }^{1}$ \\ and Su Zhenzhen ${ }^{1}$ \\ ${ }^{1}$ Key Lab of Marine Reservoir Evolution and Oil \& Gas Accumulation Mechanism of Ministry of Education, China \\ University of Geosciences, Beijing 100083, China \\ ${ }^{2}$ Institute of Petroleum Exploration and Development, Tarim Oilfield Company, PetroChina, Xinjiang 841000, China
}

(C) China University of Petroleum (Beijing) and Springer-Verlag Berlin Heidelberg 2010

\begin{abstract}
The Silurian in the Tarim Basin was deposited on the basement deformed by the Caledonian tectonic movements at the end of the Late Ordovician. The development and distribution of sedimentary sequences of the Early Silurian have been clearly controlled by the palaeogeomorphology of the Late Ordovician. Based on unconformity characteristics and distribution of erosion, several zones can be differentiated including a high uplifted erosion zone, a transitional slope zone and a depression zone. The central and west Tabei Uplift zones show high angular unconformity and intense erosion. The Tarim Basin in the late Ordovician shows characteristics of higher in the west, lower in the east while higher in the south, lower in the north. The Early Silurian mainly developed transgressive and highstand systems tracts on the whole, while the lowstand systems tract only developed partly below the slope break. The palaeogeomorphology controlled the clastic source supply and deposit distribution. Braided delta system and tidal flat-estuary system were deposited. The duration of uplifting of the Tazhong paleouplift was longer than that of the Tabei paleo-uplift, and deposition was later. This led to the lower and middle members of the Kepingtage Formation missing in that area. As a large-scale transgression occurred during the deposition period of the upper member of the Kepingtage Formation, sediment from the west of the basin was transported and deposited by tides and waves, forming tidal-marine debris systems above the uplift. Proximal alluvial fan and fan delta coarse clastic deposits developed in proximal uplift zone in the east and southeast of the basin, and braided delta put forward to the transitional zone between the edge of uplift and the sea. Large-scale tidal channel, sub-distributary channel and mouth bar of the delta front can form favorable reservoirs, and they are primary targets for oil and gas exploration. This research on sequence-depositional systems development and distribution controlled by palaeogeomorphology is significant in guiding the prediction of reservoir sandstones.
\end{abstract}

Key words: Erosional palaeogeomorphology, depositional palaeogeomorphology, evolution of paleouplift, sequence-depositional system, favorable reservoir facies zone

\section{Introduction}

The Silurian in the Tarim Basin developed within a craton deflection environment and formed a set of marine deposits with a maximum thickness of 2,000 meters. These are the Kepingtage, Tataertage and Yimugantawu formations from bottom to top, with a distribution area about $249,000 \mathrm{~km}^{2}$ in

*Corresponding author. email: lincs@cugb.edu.cn Received July 9, 2009 the whole basin. The Silurian has attracted much interest from geologists and oil industry. On one hand, the Silurian formed just after the large-scale plate movement of the Tarim Basin, and the Tarim plate's tectonic environment changed from divergent to convergent during the Late Caledonian tectonic movement in the early Paleozoic (Jia, 1997; Song et al, 2003; He et al, 2005). The basin structure pattern and overall framework have experienced significant changes, and the sedimentary environment has changed from marine carbonate which was widely distributed in Cambrian-Ordovician to 
marine clastics of the Silurian-Devonian (Zhang et al, 2002; Song and $\mathrm{Wu}, 2004$; Kang, 2004; Cai, 2005; Zhou et al, 2007). On the other hand, the widely distributed asphalt in Silurian sandstone is prominent, which indicates a large-scale oil/gas migration or accumulation. It shows huge oil and gas exploration prospects in Silurian.

Exploration of the Silurian began in 1991, and since the success of the first oil production well Tz11 in 1994, a series of hydrocarbon reservoirs have been discovered including normal oil, condensate oil and gas, heavy oil and bitumen. The second resource assessment shows a large amount of resources reaching 11.6 million tons in the Silurian, mainly in the northern part and the central uplift. Now, the Silurian has become another important marine sandstone reservoir exploration target after the Donghe sandstone in the Tarim Basin, and exploration workload and research input on the Silurian of the Tarim Basin have been increased (Xu, 2004; $\mathrm{Hu}$ et al, 2005). But due to large size of the Tarim Basin, the current exploration and study level is still low for the whole basin even there are some breakthroughs. At present, the discovered oil and gas reservoirs are mainly structure trap and unconformity trap types, which present less exploration difficulties. After that, the next exploration stage is searching for Silurian stratigraphic or lithologic traps as major exploration and research targets.

Past research into the Silurian focused mainly on stratigraphic correlation and sequence division, sedimentary system and sedimentary facies, tectonic evolution and oil/gas migration and accumulation. Much hard and sophisticated work has been done (Lü, 1997; Chen and Wang, 1999; Liu et al, 2001; Zhu et al, 2002; Liu et al, 2004; Liu and Wang, 2005; Wang and Zhang, 2006; Chen et al, 2008). However, there are still some difficulties and key factors restricting oil and gas exploration, and among them the most important are distribution prediction and evaluation of reservoir sandstone. For a marine clastic basin, the genetic mechanism of the clastic system and sedimentary facies controlled the distribution of favorable reservoir sandstone and the development of favorable stratigraphic or lithologic traps.

As a result, we focus on the early Silurian major oilbearing strata, the Kepingtage Formation, and discuss the palaeogeomorphology characteristics of early Silurian deposition period and their control on the sequence and depositional system development and distribution by means of rebuilding the prototype basin model, and sequence and sedimentary system analysis. It has a great significance in predicting the distribution of favorable reservoir sandstone and development of stratigraphic or lithologic traps (William et al, 2005; Martinsen, 2003; McCaffrey and Kneller, 2001; Ramos et al, 2006; Liu et al, 2008).

2 The sequence-tract and depositional system of the early Silurian Kepingtage Formation

\subsection{Deposit filling and sequence framework of Silurian}

Because of the variety and inconsistency of Silurian strata in the Tarim Basin, the stratigraphic contrast and sequence division of Silurian have been controversial for many years (Zhang et al, 2002). Until now, the strata in the Tazhong area have been divided by lithology, as upper, middle and lower sandstone sections; while they have been differentiated by formation in the Tabei area, as the Kepingtage, Tataertage and Yimugantawu formations. The variation of stratigraphic contrast leads to different sequence division schemes. Many geologists have studied Silurian sequence and systems tract division. Silurian deposition has also been a focus in both the oil industry and academia (Jia et al, 2006; Shi et al, 2007; Zhang and Zhang, 2008). On the whole, the Silurian formed in offshore and shallow marine environments. Questions of what type of shoreline clastic system was the major depositional system during different periods and how to predict the favorable reservoir distribution are still unresolved and remain as primary questions for oil and gas exploration due to limited scope of current drilling. There are many research results about stratigraphic contrast, sequence differentiation and classification, and depositional system. On one hand, this is based on the complexity of tectonic evolution and deposit filling, while on the other hand, it also reflects the needs for more study of the Silurian.

A framework of sequence stratigraphy has been established in this paper from interpretation of the basin's long seismic profiles and typical well data from the Tazhong and Tabei areas. There is one $2^{\text {nd }}$ order depositional cycle in the Silurian. Ordovician and Devonian are observed below and above the Silurian separated specifically by angular unconformities. There are three identifiable sub-scale unconformities and four $3^{\text {rd }}$ order sequences which are equivalent to the middle member of the Kepingtage Formation ( $\left.\mathrm{SQ}_{-} \mathrm{Sk}_{1}\right)$, the upper member of Kepingtage Formation ( $\mathrm{SQ} \_\mathrm{Sk}_{2}$ ), the Tataertage Formation (SQ_Stt) and the Yimugantawu Formation (SQ Sy) generally. These sequences can be traced and contrasted in the Tazhong and Tabei well fields. The $3^{\text {rd }}$ order sequence boundaries specifically correspond to the $\mathrm{Tg} 40, \mathrm{Tg} 41$, and Tg42 reflection surfaces on seismic profiles, which all appear with onlap on the bottom surface, truncation at the top surface and local erosion. The gradual migration of the depositional center to the south and onlap to the north can be found on seismic profiles south of the Tabei Uplift. Angular unconformity and erosional unconformities dominate the $3^{\text {rd }}$ order sequence boundaries in outcrops (Fig. 1).

Two layers of four $3^{\text {rd }}$ order sequences can be tracked and contrasted as markers in the whole region. One is the grey green mudstone of the middle member of the Kepingtage Formation ( $\mathrm{SQ} \_\mathrm{Sk}_{1}$ ) formed in a shallow marine platform environment, with a thickness of 120-150 m and widely distributed ranging from the Tabei area, basin marginal outcrop to the Manjiaer Depression area, disappearing at the Tazhong Uplift. The other one is red mudstone of the lower member of the Tataertage Formation (SQ_Stt), with a thickness of 70-1,150 m, intersected by most boreholes and also widely distributed. It was also observed at basin margin outcrop areas. The red mudstone thins out in the Tabei area, even disappears. That would be related with the palaeogeomorphology during deposition period of the Tataertage Formation (SQ_Stt), and the lack of deposition in 
the uplift belt or tectonic reverse leads to erosion and absence of strata (Fig. 2).

Integration of outcrop profiles, borehole and logging data show that the $3^{\text {rd }}$ order sequence was mainly composed of transgressive and highstand systems tracts, while lowstand systems tracts did not develop in general except in some areas below the slope break. The sequence-tract development and distribution would be related with the depositional palaeogeomorphology. Additional drilling in depression areas and understanding of the development and distribution of lowstand systems tracts is important for the next stage study of the Silurian in the Tarim Basin.

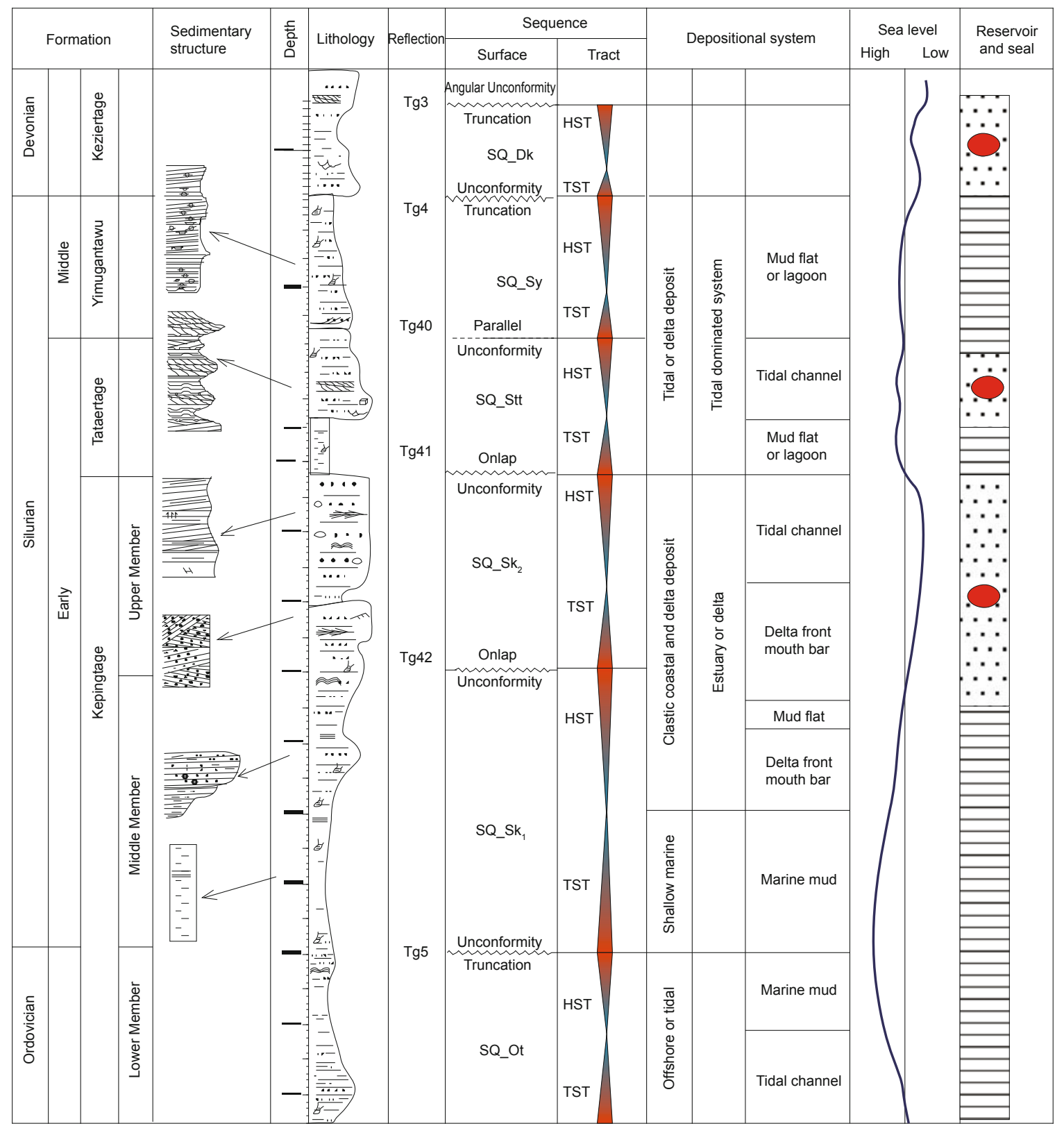

Fig. 1 The deposition and sequence classification and boundary characteristics (HST is highstand system tract, TST is transgressive system tract)

\subsection{Sequence-systems tract evolution and depositional system of Early Silurian Kepingtage Formation}

The Kepingtage Formation is an important stratum of the Silurian. The current oil and gas production of the Silurian comes mostly from this formation, especially the upper sandstone member. So in this article we mainly discuss the sequence-systems tract evolution and depositional system of the Kepingtage Formation.

There are obvious lithologic characteristics in borehole and well $\operatorname{logs}$ for the Kepingtage Formation and three members upper, middle and lower can be differentiated. In the latest strata classification, the lower sandstone member 


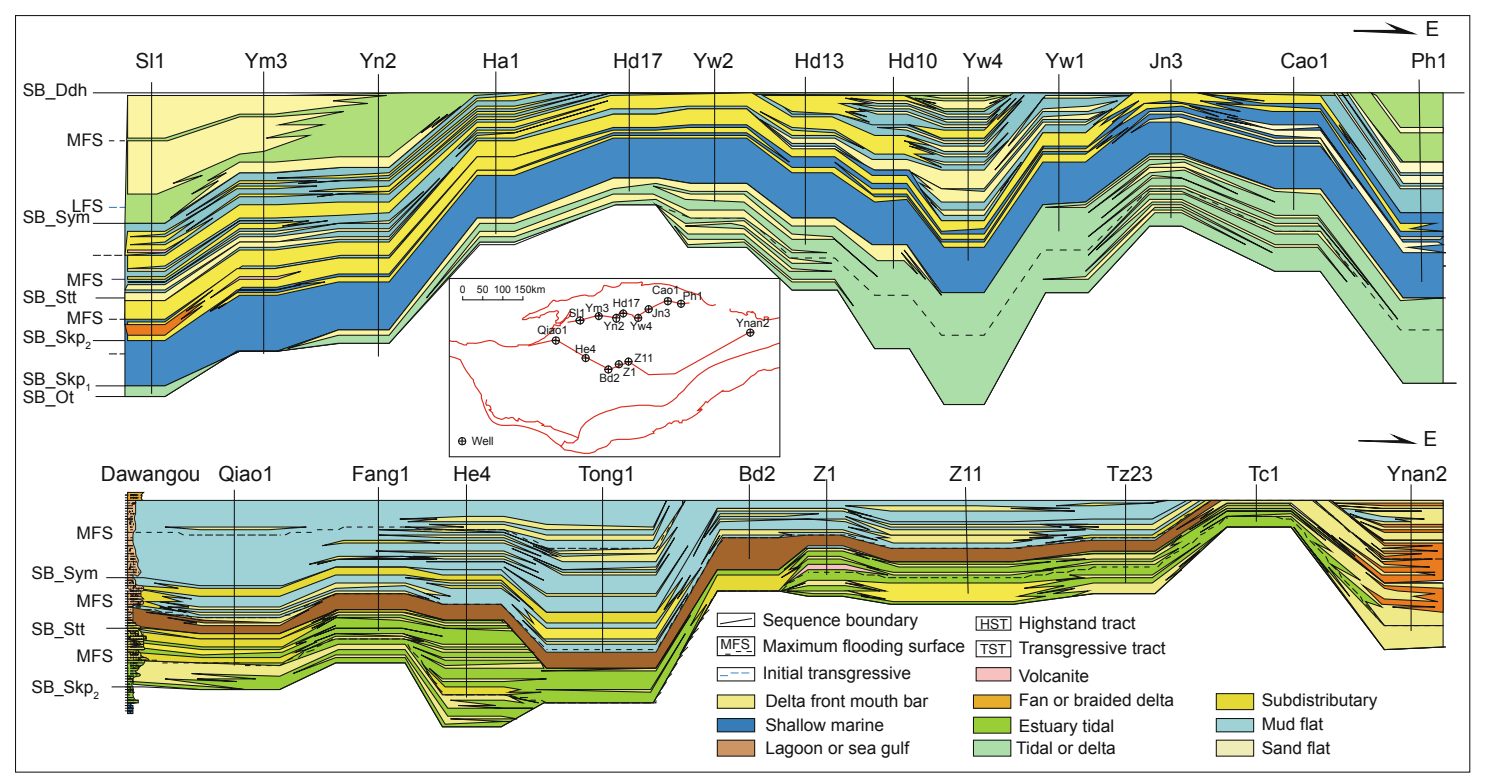

Fig. 2 The sequence-tract classification and contrast from outcrop to well logging Upper: well logging contrast profile of the Tabei area

Bottom: contrast profile from outcrop to well logging of the Tazhong and Tadong areas

of the Kepingtage Formation corresponds to Late Ordovician deposition. Therefore, it has been referred to as the Late Ordovician Awati Formation. Thus, the current Kepingtage Formation just includes the middle mudstone and upper sandstone members. Specifically, based on variations of the sand and mud contents, the upper sandstone member can be divided into three sub-sections: the upper sandstone subsection, middle mudstone sub-section and lower sandstone sub-section. They are all primary gas and oil reservoirs.

Through integrated analysis of outcrops, drill cores and well logs, the vertical filling sequence has been established in this paper (see Fig. 1). As the figure shows, an overall regressive process occurred during the depositional period of the Kepingtage Formation, which can be divided into two $3^{\text {rd }}$ order sequences ( $\mathrm{SQ} \_\mathrm{Sk}_{1}$ and $\mathrm{SQ} \mathrm{Sk}_{2}$ ), corresponding to the middle mudstone member and upper sandstone member of the Kepingtage Formation. The sequence boundary has an obvious unconformity characteristic from outcrops, seismic profiles and log data. The log has an abrupt shape change at the sequence boundary, and it is straight under the boundary while transforming to a block shape above the boundary, showing obvious truncation and erosion characteristics. Clear onlap and truncation appearances can be observed on seismic profiles. The sedimentary system evolved from early shallow marine shelf ( $\left.\mathrm{SQ} \_\mathrm{Sk}_{1}\right)$ to later clastic shoreline and delta system ( $\mathrm{SQ} \mathrm{Sk}_{2}$ ), showing overall regressive characteristics. There are also minor transgressive surfaces in sequence $S Q$ $\mathrm{Sk}_{1}$ and $\mathrm{SQ} \mathrm{Sk}_{2}$, by which transgressive systems tract and highstand systems tract can be divided. The lowstand systems tract of sequence SQ_Sk $\mathrm{Sk}_{1}$ is not clearly developed, and the lowstand systems tract of sequence $\mathrm{SQ} \mathrm{Sk}_{2}$ just developed locally below the shelf slope with incised channel deposits. In the transgressive systems tract and highstand systems tract, clastic shoreline, tidal flat-estuarine and braided delta systems developed.
Laterally, the sedimentary system of sequence $\mathrm{SQ}_{2} \mathrm{Sk}_{2}$ changes largely from coastal debris system to tidal flatestuarine system and braided delta. Through the interpretation of borehole cores, outcrops and well logs, several microfacies types can be recognized, including tidal channel, delta front sub-distributary, mouth bar, sand flat and mud flat. There are typical braided delta front mouth bar and sub-distributary deposit in the Dawangou outcrop profile of the Keping area, northwestern Tarim Basin. Within the northwestern part of the basin in Sishichang outcrop profile, not far away from the Dawangou outcrop, typical tidal fascicular texture can be observed, which reflects tidal-dominated channel deposits as in the Dawangou outcrop profile. The drill cores from the Tazhong, Tabei and Tadong areas also confirmed that there were various sedimentary systems in different parts of the basin. The shoreline sand bar, estuarine-tidal flat and braided delta developed in the Tabei area, while tidal flat was the main sedimentary system in the Tazhong area, and large-scale braided delta in the Tadong area.

(1) Braided delta systems. The Dawangou outcrop profile of the Keping area in the northwest of the basin shows largescale delta system, with typical upward coarsening grade sequence, indicating delta front mouth bar deposit (Fig. 3). The vertical sequence gradually varies from predelta mudstone to sand-mud interbed and sandy delta front mouth bar deposit. Medium or small scale cross-bedding and wave bedding develop there, and bioturbation structure and trace fossils can be observed. Large-scale distributary channel, with thickness of $30-50 \mathrm{~m}$, is made of medium and coarse sand, containing many pyrite nodules. Large-scale tabular cross-bedding and sole marking structure are visible. A delta system developed in the upper member of the Kepingtage Formation ( $\mathrm{SQ} \mathrm{Sk}_{2}$ ). Drill cores, logs and seismic profiles show typical gradually upward coarsening mouth bar deposits, and the large scale progradation architecture of delta front can be recognized on 

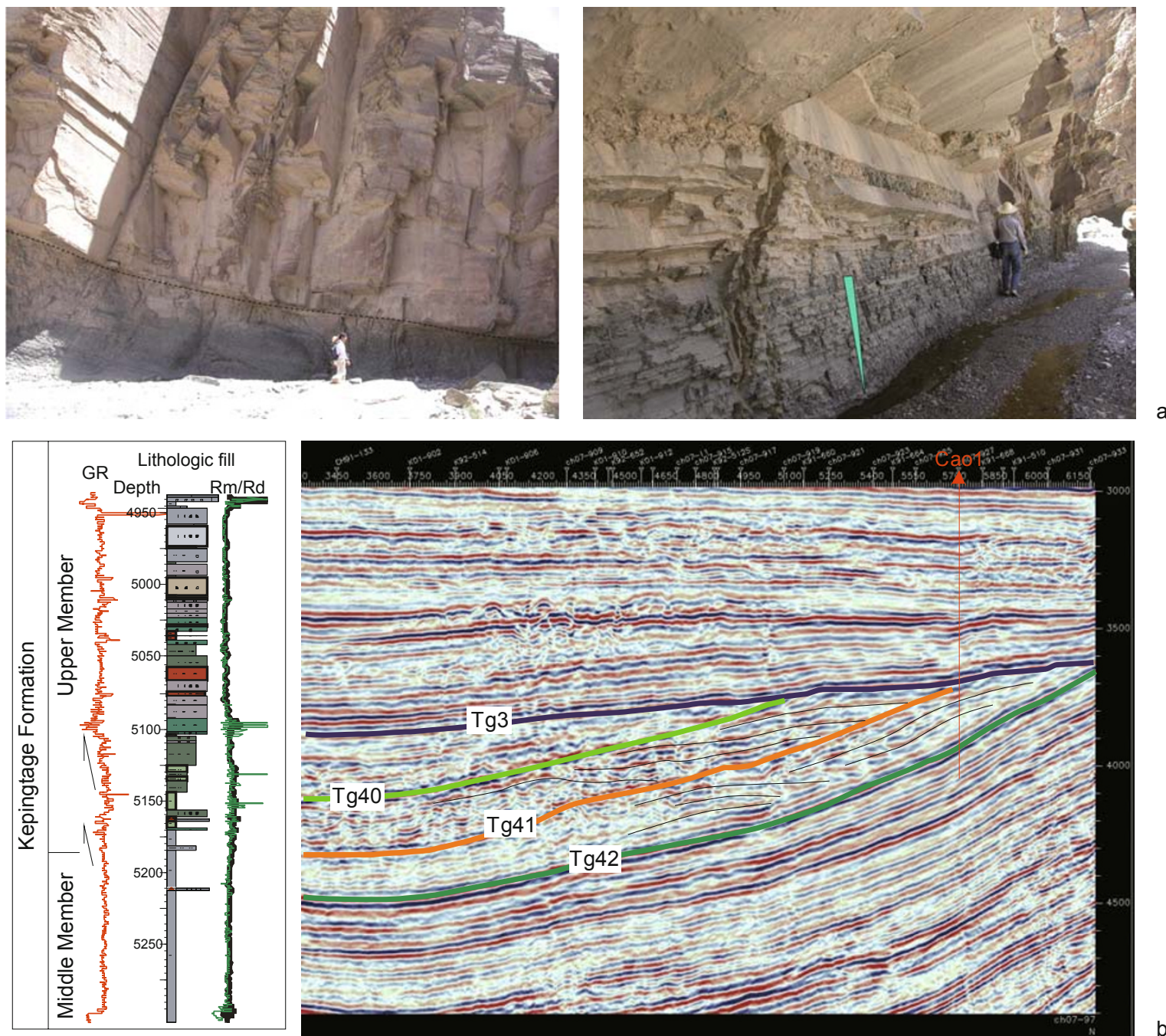

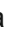

Fig. 3 The delta characteristics of the upper member of the Kepingtage Formation (SQ_Sk $)$

a: Dawangou outcrop profile (left: distributary channel; right: mouth bar)

b: Well Cao1 logging characteristics of delta and large-scale progradation architecture on the seismic profile in Tabei

seismic profiles.

(2) Tidal flat-estuarine system. The wide development of tidal flat-estuarine systems is a depositional characteristic of the Silurian in this area. Large-scale tidal channel or estuarine channel system, made of middle and coarse sandstone and truncated on the bottom, can be observed in the Sishichang outcrop profile of the Keping area in the northwestern basin. There developed large scale tabular cross-bedding, tidal fascicular texture and double clay layers, which reflect tidal action and bi-directional water flow (Fig. 4). Well-sorted tidal channel sandstone with a thickness of 15-20 m can form an important reservoir. Arenaceous pelitic facies, with linsen bedding, flattened bedding and bioturbation structures developed in the intertidal mixed flat zone. In drill cores from the Tazhong Uplift, tidal channel sandstone, mainly medium grade sandstone, and all kinds of tidal bedding can be found.

The development of sedimentary systems in different regions in Tarim Basin reflects the combined effect of palaeogeomorphology, sea level changes and tectonic activities.

\section{The structural (or erosion) palaeogeomorphology before the early Silurian deposition of the Tarim Basin}

\subsection{Unconformity characteristics and distribution at the end of the late Ordovician}

The Caledonian tectonic movement at the end of the late Ordovician in the Tarim Basin is the most important movement of early Paleozoic. This had a significant impact on the whole formation and evolution of the Tarim Basin, and made the Tarim Basin change from the Sinian-Ordovician extension stage to the Silurian-Devonian craton compression deformation stage. Meanwhile, the type of sedimentary system varied from the dominant Ordovician carbonate sediments to the Silurian-Devonian clastic sediments. The subduction compression at the southern and northern margins of the Tarim plate represents the main Late Caledonian tectonic movement, while the island arc volcanic activity at the northern margin of the Tarim plate reveals the strong 

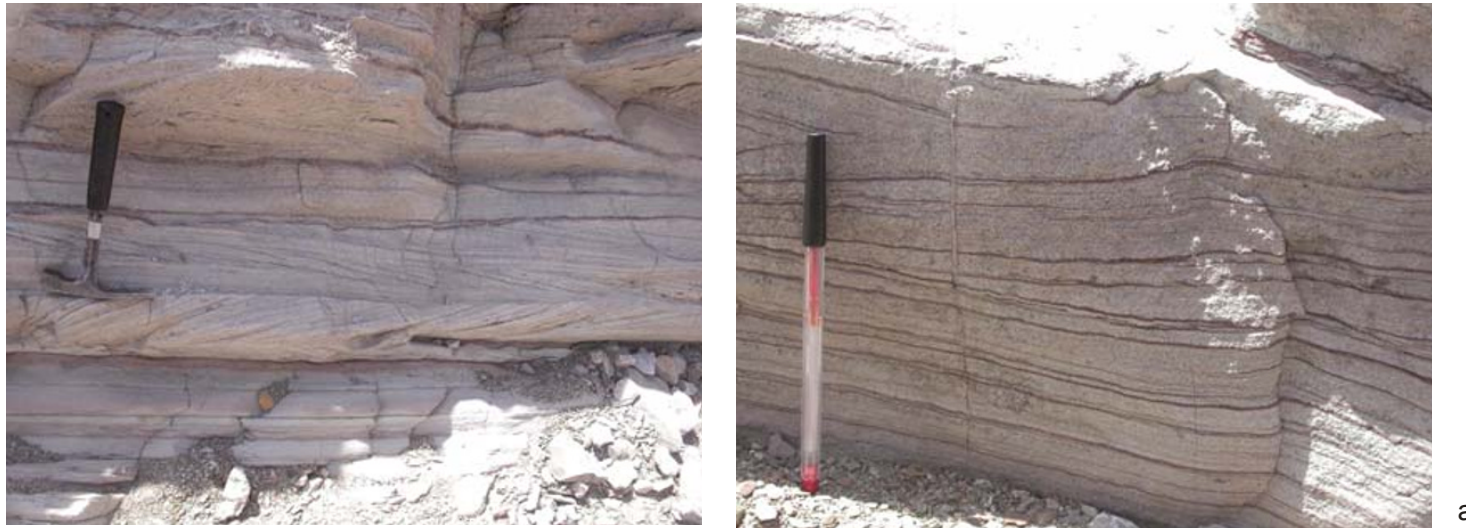

a

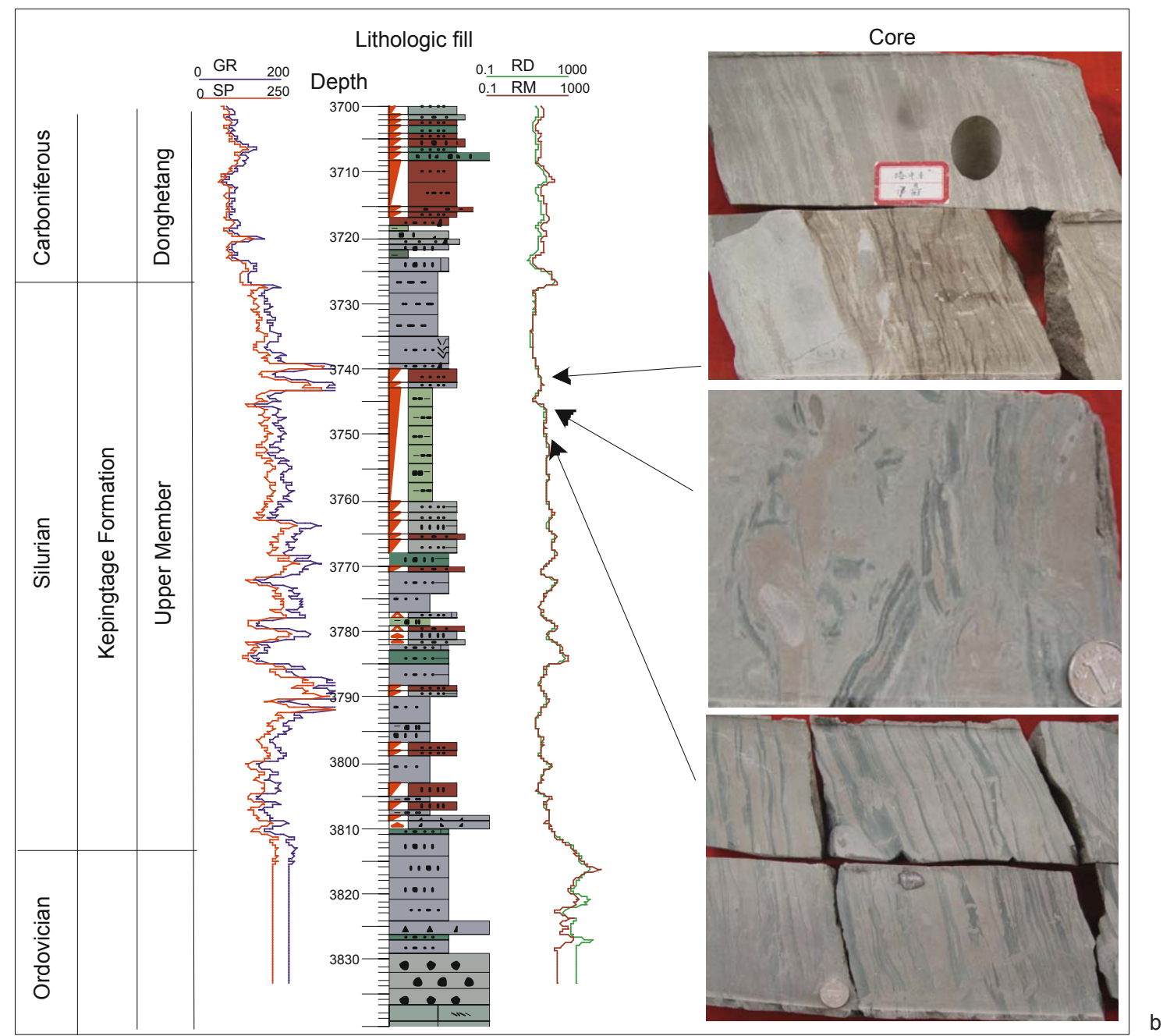

Fig. 4 Tidal flat-estuarine system characteristics of the upper member of the Kepingtage Formation (SQ_Sk ${ }_{2}$ ) a: tidal channel deposit of the Sishichang outcrop profile (left: herring bone bedding; right: double clay layers) b: logging characteristics and drilling core features of the tidal flat system in the Tazhong area (well TZ4)

subduction of the ancient ocean plate into the middle section of the southern Tianshan Mountain. The island arc of the middle Kunlun Mountain and Qimantage accretion subduction petromictic rock also proved the strong subduction of the ancient Kunlun Ocean plate of the southern Tarim Basin into the middle Kunlun block (Shi et al, 2007). The intense compression from both southern and northern parts of Tarim Basin led to crustal shortening and large scale uplift, causing extensive regression, exposed strata and erosion, and formed the widespread regional angular and erosion unconformities, clearly showing a truncation reflection characteristic (Tg5) on seismic profiles. Shi et al (2007) also proved the discontinuity of this tectonic event from palaeophyte fossil assemblage. L.balfica-T.bergstroemi developed below the boundary while Conochitinasp. 2 developed above the boundary.

Silurian clastic deposits formed after the Late Caledonian tectonic movement, during the period of the plate tectonic stress release, compaction weakening and global sea-level 
rise. Based on the tracing and interpretation of seismic profiles, rebuilding the unconformity model and recalibrating the unconformity caused by the Late Caledonian tectonic movement at the end of the Late Ordovician is significant in characterizing the tectonic activity strength, distribution and understanding the palaeogeomorphology of Early Silurian.

The study reveals a great difference in the unconformities of Late Ordovician. Several unconformity patterns can be recognized: high angular unconformity, angular unconformity, slight angular unconformity, onlap unconformity, parallel unconformity and paraconformity.

Unconformity boundary Tg5 strongly truncated underlying strata in local areas, and even truncated the Tg51 unconformity, formed overlapping unconformities of $\operatorname{Tg} 5$ and $\operatorname{Tg} 51$, led to the lower unconformity being missing, which is called superposition unconformity. $\operatorname{Tg} 5$ and $\operatorname{Tg} 51$ superposition unconformities can be found in the southwestern Tarim Basin, and it reflects significant uplift and erosion. Unconformity boundary $\mathrm{Tg} 5$ appears with high angular and angular unconformities in the Tazhong area, and strong truncation of underlying Late Ordovician strata and the onlap characteristics of overlying Silurian have been discovered. Tg5 varies from east to west in the Tabei area. In the western Yingmaili area, Tg5 appears as high angular unconformity and angular unconformity, and strongly truncates underlying strata (Fig. 5), while in the eastern area, the unconformity characteristics are not so obvious, mainly showing parallel unconformity or conformity contact, paralleling upper and lower strata. In a basin scope, except for the southwestern, central uplift zone and Tabei area with obvious angular unconformity characteristics, the Manjiaer and Awati depressions appear as parallel unconformity or conformity, and slight angular unconformity is the transitional part between conformity and angular unconformity. From uplift to depression, the pattern and distribution of unconformity boundary $\mathrm{Tg} 5$ can be divided into unconformity superposition zone in high uplift, unconformity truncation triangle zone in marginal uplift or onlap triangle zone, slight angular unconformity or parallel unconformity zone, and depression conformity zone. The unconformity pattern and distribution directly reflect the tectonic movement strength and trends.
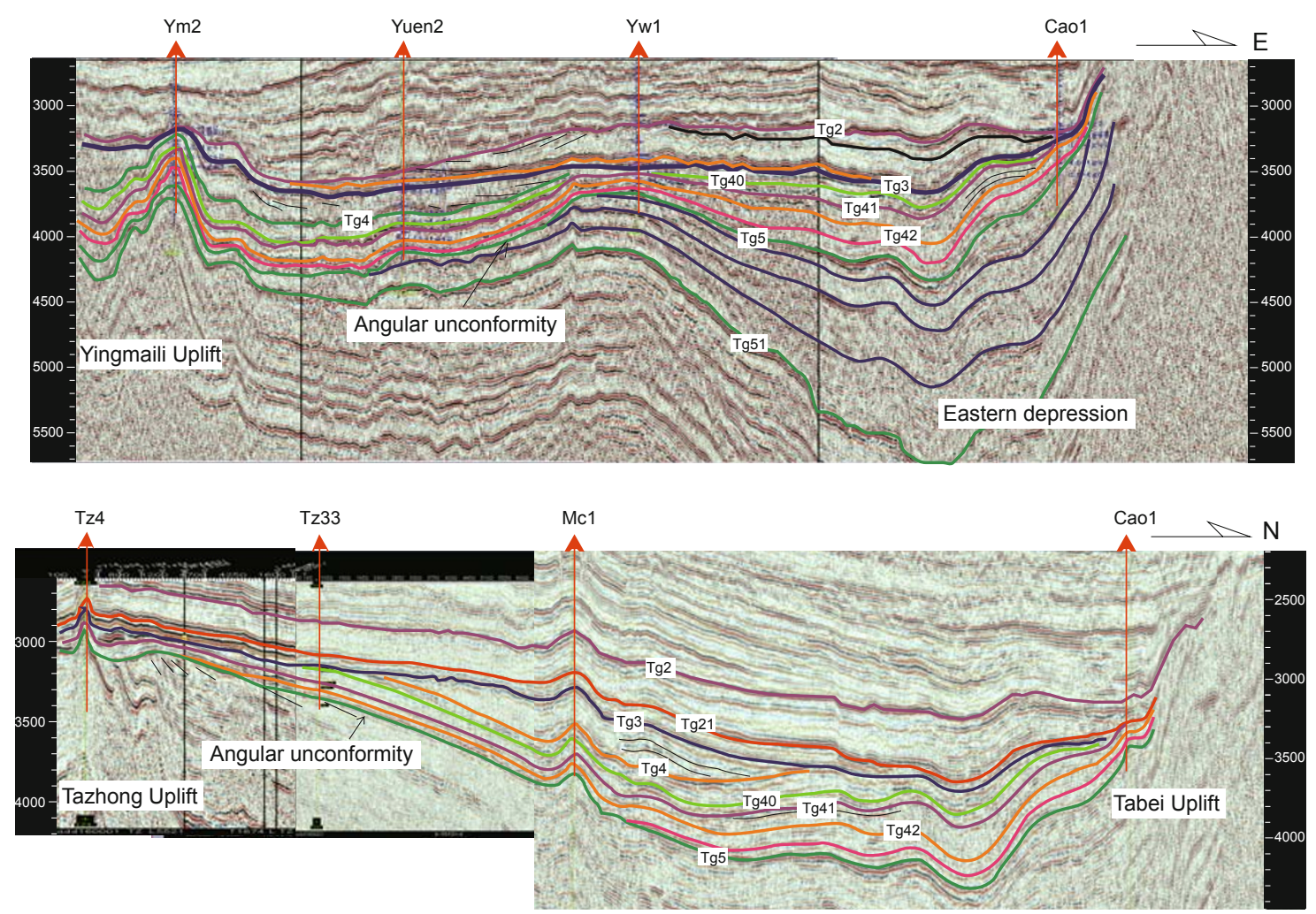

Fig. 5 The unconformity (Tg5) characteristics and erosion trend analysis of the Late Ordovician Upper: Variety of unconformity styles from west to east of the Tabei area

Below: Unconformity style contrast between Tazhong and Tabei showed by the N-S seismic profile of the Tarim Basin

\subsection{The erosion palaeogeomorphology and uplift- depression framework at the end of Late Ordovician}

Tg5 unconformity style analysis shows that the variation from high angular unconformity to slight angular unconformity or parallel unconformity, even paraconformity contact, reveals the palaeogeomorphology changing from high uplift erosion zone to slope zone and depression. The Tarim Basin is a large scale superimposition basin with Palaeozoic fillings and thick deposits of Mesozoic and Cenozoic. The total depth of the Tarim Basin is over 10,000 m and the burial depth of Tg5 is large due to large-scale subsidence and filling in late period, so favorable methods for erosion estimation 
are limited. The reflection configuration extrapolation method (strata configuration similarity comparison) has been applied to erosion trend analysis in this study in order to avoid various ambiguous interpretations and for effective usage of data. The erosion amount has been estimated by drilling calibration and velocity-depth model adjustment. The erosion distribution and trend mapping of the $\operatorname{Tg} 5$ unconformity surface has been done. Based on these, a series of palaeogeomorphology units have been identified (Fig. 6).

As Fig. 6 shows, the erosion palaeogeomorphology can be divided into three different erosion belts from south to north: southern uplift-erosion belt, middle depression belt and northern uplift-erosion belt. The southern uplift-erosion belt covers most of southwestern and southern Tarim Basin dominated by superposition unconformities and angular unconformities, and the strongest uplift and erosion is located at the southern margin of the basin, while weakening in the north. The whole unconformity pattern and erosion distribution shows that two strongly eroded areas occur on the southern margin of the basin. One is the western uplift, extending in a NE or NNE direction, with a maximum erosion thickness of $1,000 \mathrm{~m}$ and the other one is the central uplift belt, extending NW or NNW, with a maximum erosion thickness of 3,000 m. According to the erosion and trend, a series of palaeogeomorphology units can be identified from the southern uplift area to the northern depression, including the strongly eroded high uplift zone, paleo-uplift marginal slope zone, depression marginal ramp zone and depression zone (Fig. 6) with decreasing erosion trend. The unconformity also shows a general variation trend from superposition unconformity to high angular unconformity, angular or slight angular unconformity, parallel unconformity and conformity. The Tabei paleo-uplift also shows similar palaeogeomorphology distribution with a maximum erosion thickness about 1,500 $\mathrm{m}$, and paleo-uplift and erosion are mainly distributed in the western Yingmaili lower uplift area. Based on the variation from high angular unconformity to slight angular unconformity and conformity, several palaeogeomorphology units can be defined, such as high uplift erosion zone, slope erosion zone and depression zone.

As a whole, the erosion palaeogeomorphology during this period has a feature of higher in the west, lower in the east, higher in north and south, and lower in the centre, showing a topographic structure divided from east to west and zoned from south to north. The palaeogeomorphology controlled the sedimentary facies distribution of the Early Silurian.

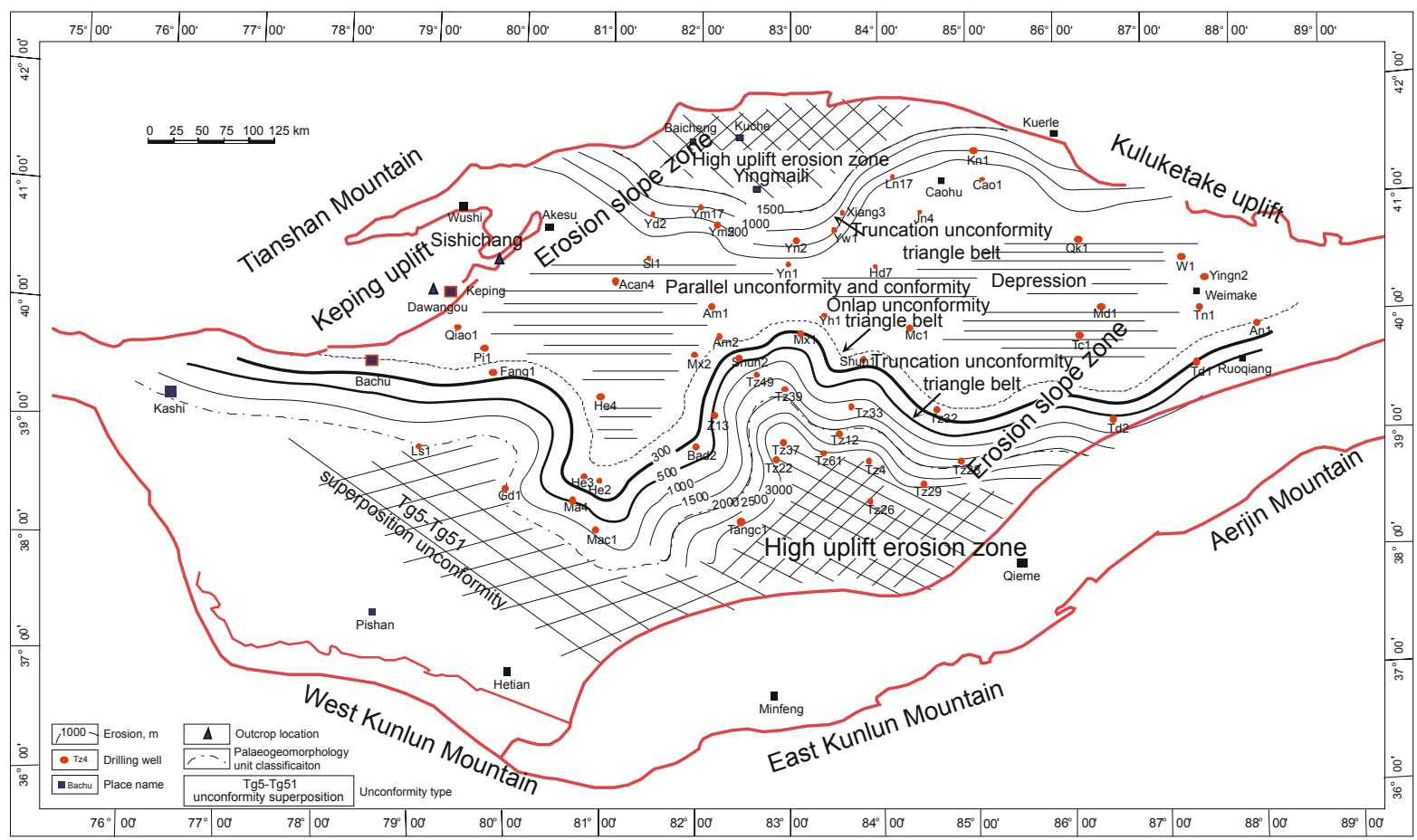

Fig. 6 The erosion distribution and palaeogeomorphology characteristics of Late Ordovician unconformities in the Tarim Basin

4 Palaeogeomorphology evolution and its control on the sequence-depositional systems development and distribution

\subsection{The palaeogeomorphology characteristics and paleo-uplift evolution of the Early Silurian}

The erosion palaeogeomorphology characteristics of the end of the Late Ordovician in the Tarim Basin, revealed by the unconformity and erosion trend analysis above, reflect the bulge and depression framework, indicating the existence of the Central Uplift and Yingmaili low uplift in Tabei area. The Tarim Basin experienced a multicycle history from subsidence and filling to uplifting and erosion, the depositional filling of each cycle was controlled by the palaeogeomorphology and paleo-uplift evolution (Lin et al, 2004b). In general, a 
typical evolutionary cycle of the uplift can be divided into the following three stages (Lin et al, 2004a; 2009): (1) The initial or underwater uplifting stage before the uplift rose above the water level, the overlying deposits became thinner toward the top of the uplift and formed a shoaling upward depositional sequence. Then the uplift was a kind of "depositional uplift". (2) The major uplifting or eroding stage after the uplift rose above the water level and was eroded, causing a stratigraphic hiatus and generating an unconformity. The uplift became "eroded uplift". (3) The following subsidence stage when the uplift subsided again with stratigraphic onlap on the unconformity, forming a deepening upward depositional sequence. It was also a kind of "depositional uplift". Obviously, it is necessary to identify different development stages before reconstructing the palaeogeomorphology of the uplift. The paleo-uplift of the Late Ordovician was still in the first two stages, from beginning of uplift to erosion. According to the continuity of paleo-uplift evolution, what is the palaeogeomorphology characteristic of Early Silurian? Does the early paleo-uplift still exist? And has it entered the third evolution stage and began to accept deposit?

These problems can not be solved simply in aspect of paleo-uplift evolution, and we can only work through a large amount of drilling, logging and seismic reflection data to identify all kinds of sedimentary signals and diagnose the paleo-uplift evolution stage and its control on depositional filling.

Comparing primary drilling data of the Tazhong and Tabei areas (Fig. 7), the lower member of the Kepingtage Formation (which has been reclassified as the Late Ordovician Tierekeawati Formation in recent strata classification schemes) and the middle member of the Kepingtage

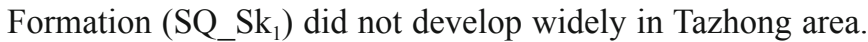
The upper member of the Kepingtage Formation (SQ_Sk ${ }_{2}$ ) deposited directly above the $\mathrm{Tg} 5$ unconformity, reflecting the large-scale uplifting of the Central Uplift zone caused by the Caledonian tectonic movement at the end of the Late Ordovician. This was an uplift above the water level without sedimentation in the Early Silurian, until the deposition period of the upper member of the Kepingtage Formation ( $\mathrm{SQ} \mathrm{Sk}_{2}$ ), when it was covered by a large scale transgression. Obvious onlap characteristics can be identified on seismic profiles, showing the broadening of the water body and upward onlapping of the sediments (Fig. 7). Different from the Tazhong area, the drilling data from the Tabei uplift area reveal that the lower member of the Kepingtage Formation (that is, Tierekeawati Formation) and the middle member of the Kepingtage Formation ( $\mathrm{SQ} \mathrm{Sk}_{1}$ ) developed very well with large thickness, except for the lower member of the Kepingtage Formation (Tierekeawati Formation) in the western Yingmaili low uplift area accepting deposit from the $\mathrm{SQ} \mathrm{Sk}_{1}$ period. That reflects the difference between west and east of Tabei area. There was continuous deposit filling and no hiatus in east, while the western Yingmaili low uplift was exposed in the early stage and suffered erosion, then began to subside and be filled later. The palaeogeomorphology and sedimentary characteristics reveal Caledonian tectonic movement at the end of the Late Ordovician was relatively weak in Tabei area, and there was no long-term large-scale uplift. The unconformity characteristic of Tg5 on seismic profiles was not as obvious and strong as that in the Tazhong area.

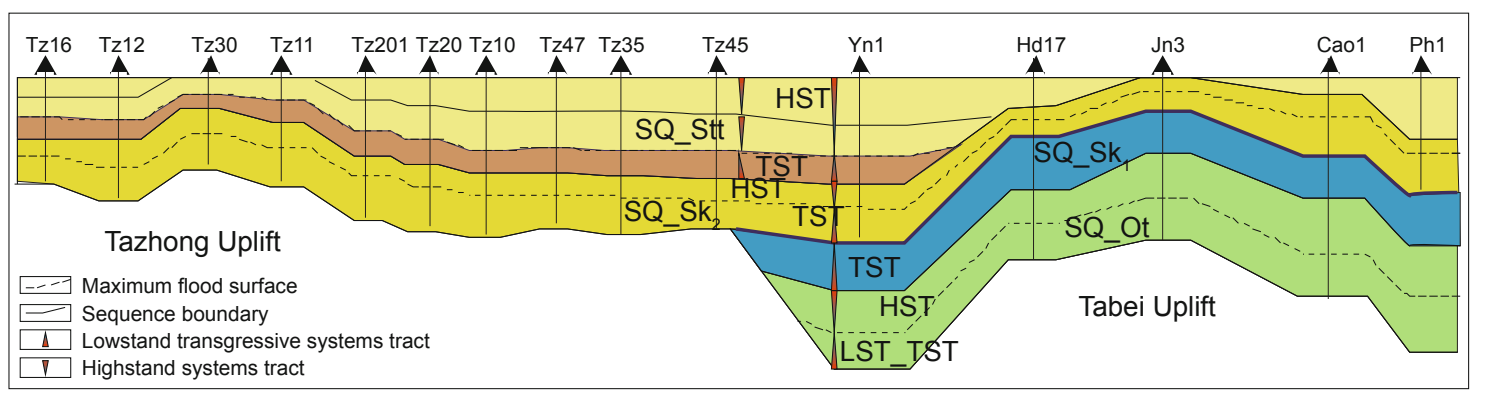

Fig. 7 Tazhong and Tabei paleo-uplift evolution and sequence--sedimentary system contrast profile

Based on all the above analysis, in the Early Silurian, the paleo-uplift was still in the second evolution stage, and entered into the third evolution stage during the period of the upper member of the Kepingtage Formation ( $\mathrm{SQ} \mathrm{Sk}_{2}$ ). The duration of the second evolution stage in Tabei Uplift area was so short that it began to accept filling in the Early Silurian (middle member of the Kepingtage Formation (SQ_Sk $\left.)_{1}\right)$. The evolution of paleo-uplift controlled the sedimentary distribution and source system.

\subsection{The paleo-uplift geomorphology and sequence-depositional system development and distribution}

The palaeogeomorphology and sedimentology research has been a hot international topic in recent years. Many people have noticed the relationship between paleouplift geomorphology and sequence-depositional system development and distribution, especially the tectonic evolution effect on the geomorphic evolution, palaeodrainage, incised valley fills and transgressive systems tract sedimentation (Plint and Wadsworth, 2003; Lin et al, 2004a; 2009; Coswami et al, 2009; Green, 2009).

The structural palaeogeomorphology and depositional system mapping of the upper sandstone member of the Kepingtage Formation ( $\mathrm{SQ}_{-} \mathrm{Sk}_{2}$ ) - the main reservoir of Silurian in Tarim Basin (Fig. 8) was derived from integrated outcrop, well drilling and seismic data, combined with source system research results (Shi et al, 2007; Jia et al, 2006), based 
on statistics of about 100 wells' sand-bearing rate (that is, the proportion of sand-sized grains in the sediments). As the figure shows, the general sand-bearing rate is relatively high in uplift belt or the edge of basin, more than $60 \%$, except for the Tazhong Uplift. From uplift to the center of depression, the sand-bearing rate decreases, and it becomes $20 \%$ in the Manjiaer and Awati depressions. The sand-bearing rate was relatively high at the middle zone of the Tazhong Uplift, about $40 \%-60 \%$, and in southern high uplift zone, the sandbearing rate decreased. From the distribution of high sandbearing rate, outcrops, drill cores, logs and seismic reflection characteristics, five structural palaeogeomorphology and sedimentary facies units can be identified. These are: (1) Tabei uplift slope belt: coastal debris-delta system; (2) Tazhong uplift ramp belt: tidal flat-delta system; (3) Keping uplift front belt: tidal flat-delta system; (4) Tadong area: near source fan-braided delta coarse clastic system; (5) Awati-Manjiaer depression: shallow marine shelf deposit. The development of sediment system was closely related to palaeogeomorphology.

(1) Tabei uplift slope belt: coastal debris-delta system. Near the northern uplift, according to the characteristics of palaeogeomorphology and the variation of depositional systems, the central and western coast debris-delta depositional zone and eastern delta depositional zone can be divided further. Because of the steep slope and near source of the eastern area, large-scale delta system developed from the northeastern influx, and the logs show rhythmic cycling reflecting the delta front mouth bar deposit. Large-scale progradation can also be observed on seismic profiles mainly in the Caohu sag. In central and western areas, near the northern uplift, especially the concave bank belt, the sandbearing rate becomes higher, and thick sandstone revealed by drilling has massive or box-shape log response, reflecting delta front sub-distributary channel features. Corresponding with the delta front belt, the sand-bearing rate in the area of parallel shoreline decreases relatively, and the contours appear straight shaped, reflecting the broad coastal environment. It was in shoreface and foreshore belt, in changing to offshore and shallow marine shelf environment in direction of the depression. In the transitional zone between the centre and east, there were some concave bank zones, and at the time the tidal forces became stronger and the estuary-tidal flat system formed. The typical tidal flat sedimentary characteristics can

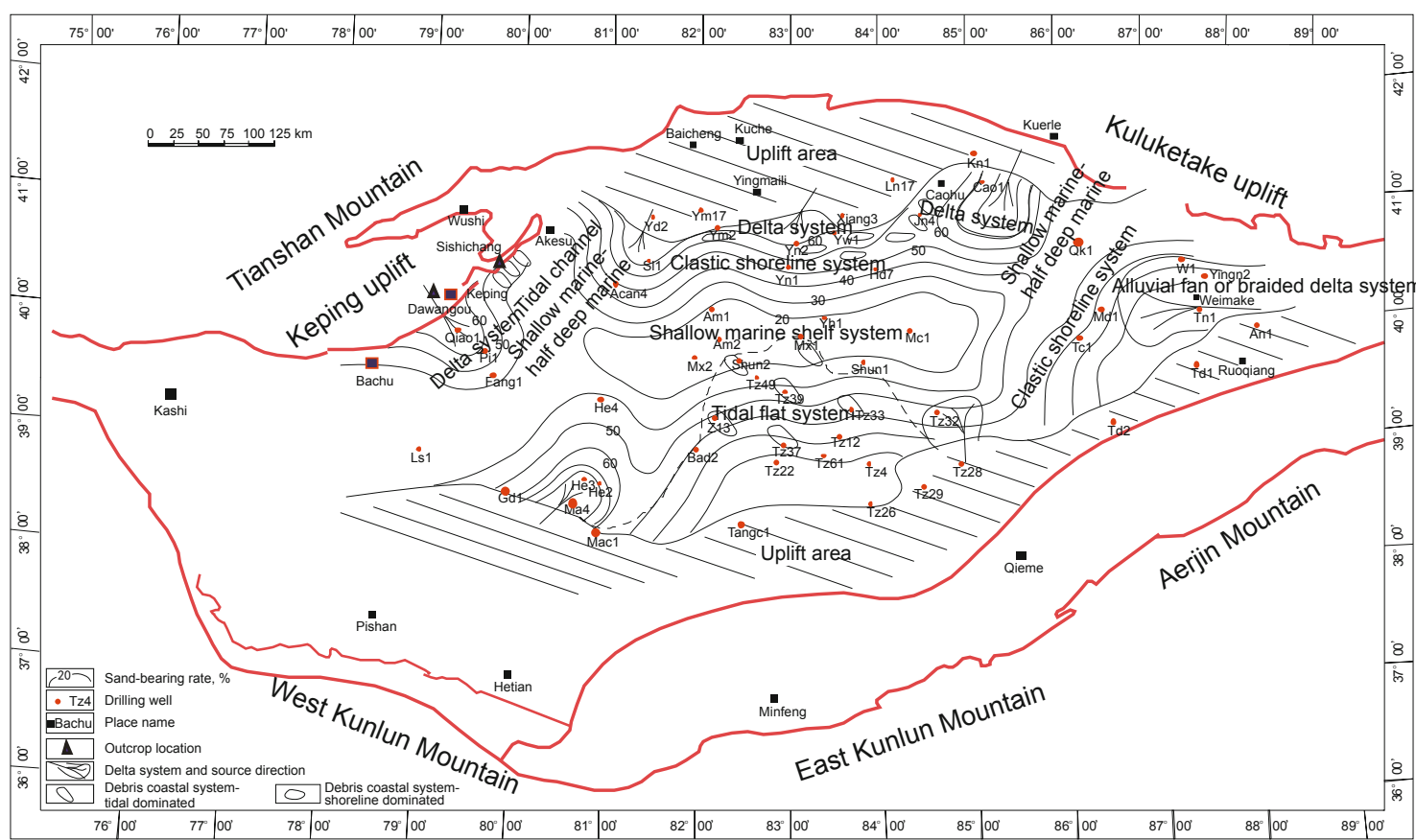

Fig. 8 The structural palaeogeomorphology and depositional system development and distribution of the Early Silurian upper sandstone member of the Kepingtage Formation (SQ_Sk $)$

be observed from drill cores.

(2) Tazhong uplift ramp belt: tidal flat-delta system. The central uplift belt extended a large distance in a gentle slope, and it has been gradually eroded flat after long-term exposure and erosion till the deposition of the upper sandstone member of the Kepingtage Formation ( $\left.\mathrm{SQ} \mathrm{Sk}_{2}\right)$. The geographic feature of the Central Uplift created the winding coastline which focused and strengthened the tidal energy, making the tidal system to be the primary sedimentary system.
The intertidal sandstone, subtidal sand flat and mud flat developed widely on the Tazhong uplift belt, and large-scale tidal channels can be found locally with sand-bearing rate ranging from $40 \%$ to $60 \%$. The sand-bearing rate decreased in the south uplift area reflecting the increase of mud flat of the supratidal zone. Some concave bank areas, on both eastern and western sides of Central Uplift, show high sandbearing rates to the south margin of uplift, indicating possible development of fluvial influx and delta. 
(3) Keping uplift front belt: tidal flat-delta system. This facies belt can be observed in detail at the Dawangou and Sishichang outcrop profiles in the Keping area of the northwestern Tarim Basin. Although the two locations are close, the sediments are significantly different. There was a typical delta system in the Dawangou profile, developing upward coarsening delta front mouth bar sequences; while the other one was typical tidal channel deposition in the Sishichang outcrop profile with obviously observed tidal fasciculation and double clay layers. The depositional characteristics relate to the shape of shoreline at that time. The coast in the Sishichang outcrop profile has a winding shape, focusing the tidal energy and developing tidal system deposits. The delta system developed in an area near the Dawangou profile with near source and steep terrain characteristics favorable for fluvial influx.

(4) Tadong area: near source fan-braided delta coarse clastic system. Drill holes in the Tadong area intersected coarse clastics such as gravel and sandstone (for example, well Yingdong 2), reflecting the near source characteristics. They also revealed the eastern Kunlun orogenic belt uplifting, resulting in sediment transport towards the basin and near source deposition.

(5) Awati-Manjiaer depression: shallow marine shelf deposit. In the early Silurian, the Tarim Basin was extending in an east-west direction, higher in south and north while lower in central area. Sea water flowed into the basin from the east and west, forming shallow marine shelf deposit in the Awati and Manjiaer depressions.

In summary, the Tarim Basin was a craton depression in the Early Silurian. From north to south, three structure units developed. These are the Tabei foreland uplift, AwatiManjiaer depression, and Central Uplift extending E-W direction. The Tabei Uplift was relatively steep developing shoreline debris-delta system generally, dominated by tidal flat-estuary system in local parts. The larger Central Uplift was characterized by gentle slopes, stable structure and winding shoreline, mainly developing tidal flat system and delta locally. In the east-west direction, tidal and delta system developed in the northwest and alluvial fan or braided delta coarse clastic deposit developed in the southeast of the Tarim Basin. The sedimentary facies types and distribution were closely related to palaeogeomorphology and coastal types.

\section{Conclusions}

1) At the end of Late Ordovician, the Tarim Basin's palaeogeomorphology framework was higher in the west, lower in the east while higher in the south, lower in the north. High angular truncated unconformity and intense erosion was generally distributed in the Tazhong and Tabei paleo-uplift belts. From high uplift to depression, the transitional slope zone can be divided with the sequence architecture showing obvious onlap characteristics. The palaeogeomorphology variation from the strongly eroded high uplift to uplift marginal slope belt, gentle ramp of the depression margin and the depression belt controlled the Silurian sequence-tract and development and distribution of deposition system.

2) The impact of the Caledonian tectonic movement in the Late Ordovician on the Tabei and Tazhong areas was very different. The Yingmaili paleo-uplift developed at the west of the Tabei area, experienced strong uplifting and erosion of the underlying Ordovician with no filling during the deposition period of the lower member of the Kepingtage Formation. Different from the west, the east of the Tabei area experienced continuous subsidence with thick Ordovician and Silurian sediments being deposited. Comparatively, the impact of Caledonian tectonic movement of Late Ordovician on Tazhong was stronger with long-term and large scale uplifting, with absence of the lower and middle members of the Kepingtage Formation. During a large sea level rise, the upper member of the Kepingtage Formation began to overlap onto the paleo-uplift. The sequence was mainly of transgression and highstand tracts, and the lowstand tract just developed partly below the slope.

3) The undulating terrain of uplift formed interlacement of highland and lowland, and paleotopography controlled the development of delta systems and near source clastic supply. Fluvial delta correlated with tidal flat deposit developed at the northwestern and northeastern of the Tabei area with clastic supply from the Tianshan Mountain. In the Tazhong area, during the period of deposition of the upper member of the Kepingtage Formation, tides and waves carried large amounts of material from the west and northwest and overlapped it on the uplift, forming tidal and shoreline debris system. At the east and southeast uplift area, proximal alluvial fan or braided delta coarse clastic deposition developed. At the edge of uplift and the slope transition zone, deltas moved forward into the sea. Large-scale tidal channel, delta front sub-distributary and mouth bar facies form favorable reservoirs, and they are the main targets for oil and gas exploration. The study of development and distribution of the sequence-sedimentary system controlled by structural palaeogeomorphology has a significant meaning in guiding the prediction of the reservoir sandstones.

\section{Acknowledgements}

This research is funded by the National Key Basic Research Program (973) (No. 2006CB202302), National Natural Science Foundation Program (No. 40372056), Fundamental Research Funds for the Central Universities (2010ZD07), and the Frontier Research Project of Marine Facies (Evolution of the Tarim Basin and Surrounding Area and Petroleum Resource Prospecting). Drs. Yang Haijun, Han Jianfa and Gao Hongliang of Tarim Oilfield Company of PetroChina all provided their supports and contributed for this study.

\section{References}

Cai X Y. Reservoiring conditions and exploration targets in the Tarim Basin. Oil \& Gas Geology. 2005. 26(5): 590-597 (in Chinese)

Chen F H and Wang G W. On logging-sequence stratigraphy of the Silurian in the Tazhong area, Tarim Basin. Acta Sedimentologica Sinica. 1999. 17(1): 58-62 (in Chinese)

Chen Y Z, Wang Y, Zhang D J, et al. Characteristics of the Silurian hydrocarbon accumulation in the southern Tahe region, Tarim Basin. Petroleum Geology \& Experiment. 2008. 30(1): 32-36 (in Chinese) 
Coswami P K, Pant C C and Pandey S. Tectonic controls on the geomorphic evolution of alluvial fans in the Piedmont Zone of Ganga Plain, Uttarakhand, India. Journal of Earth System Science. 2009. 118(3): 245-259

Green A N. Palaeo-drainage, incised valley fills and transgressive systems tract sedimentation of the northern KwaZulu-Natal continental shelf, South Africa, SW Indian Ocean. Marine Geology. 2009. 263(1-4): 46-63

He D F, Jia C Z, Li D S, et al. Formation and evolution of the multicycle superimposed Tarim Basin. Oil \& Gas Geology. 2005. 26(1): $64-77$ (in Chinese)

Hu J F, Lü X X, Zhao F Y, et al. Controlling factors on petroleum accumulation in Silurian reservoirs in the Tazhong Uplift of the Tarim Basin. Acta Sedimentologica Sinica. 2005. 23(4): 734-739 (in Chinese)

Jia C Z. Structural Characteristics and Petroleum of the Tarim Basin, northwest China. Beijing: Petroleum Industry Press. 1997 (in Chinese)

Jia J H, Zhang B M, Zhu S H, et al. Stratigraphy, sedimentary characteristics and lithofacies palaeogeography of the Silurian in Tarim Basin. Journal of Palaeogeography. 2006. 8(3): 339-351 (in Chinese)

Kang Y Z. Re-discussion of the exploration potential of the Paleozoic in the Tarim Basin: 20th anniversary of the significant discovery in the Shacan2 well. Oil \& Gas Geology. 2004. 25(5): 479-483 (in Chinese)

Lin C S, Wang Q H, Xiao J X, et al. Depositional sequence architecture and filling response model of the Cretaceous in the Kuqa Depression, Tarim Basin. Science in China, Series D: Earth Sciences. 2004a. 47(z2): 86-96

Lin C S, Yang H J, Liu J Y, et al. Paleostructural geomorphology of the Paleozoic central uplift belt and its constraint on the development of depositional facies in the Tarim Basin. Science in China, Series D: Earth Sciences. 2009. 52(6): 823-834

Lin C S, Zheng H R, Ren J Y, et al. The control of syndepositional faulting on the Eogene sedimentary basin fills of the Dongying and Zhanhua sags, Bohai Bay Basin. Science in China, Series D: Earth Sciences. 2004b. 47(9): 769-782

Liu H and Wang Y M. Early Paleozoic palaeogeomorphologycharacteristics of slope break zones and their control on stratigraphiclithologic traps in Tarim Basin. Oil \& Gas Geology. 2005. 26(3): 297-303 (in Chinese)

Liu J D, Zhang S N, Tian J C, et al. Discussion on exploration direction and depositional system of the Silurian-Devonian in the Tarim Bain, China. Journal of Chengdu University of Technology (Science \& Technology Edition). 2004. 31(6): 654-657 (in Chinese)

Liu J Y, Lin C S, Peng L, et al. Distribution patterns of the end of the Middle Devonian tectonic unconformity and their constraints on the development and distribution of favorable stratigraphic traps in the Tarim Basin. Oil \& Gas Geology. 2008. 29(2): 268-275 (in Chinese)

Liu L F, Zhao J Z, Zhang S C, et al. The depositional and structural settings and the bituminous sandstone distribution characters of the Silurian in the Tarim Basin. Acta Petrolei Sinica. 2001. 22(6): 11-18 (in Chinese)
Lü X X. Preliminary investigation on the formation mechanism of Silurian reservoirs in the Tazhong low-uplift of the Tarim Basin. Experimental Petroleum Geology. 1997. 19(4): 328-331 (in Chinese)

Martinsen R S. Depositional remnants, part 1: Common components of the stratigraphic record with important implications for hydrocarbon exploration and production. AAPG Bulletin. 2003. 87(12): 18691882

McCaffrey W D and Kneller B C. Process controls on the development of stratigraphic trap potential on the margins of confined turbidite systems and aids to reservoir evaluation. AAPG Bulletin. 2001. 85(6): 971-988

Plint A G and Wadsworth J A. Sedimentology and palaeogeomorphology of four large valley systems incising delta plains, western Canada Foreland Basin: implications for mid-Cretaceous sea-level changes. Sedimentology. 2003. 50(6): 1147-1186

Ramos E, Marzo M, de Gibert J M, et al. Stratigraphy and sedimentology of the Middle Ordovician Hawaz Formation. AAPG Bulletin. 2006. 90(9): 1309-1336

Shi Z S, Yang W, Guo C M, et al. Depositional sequence and filling response characteristics of the Silurian in the Tarim Basin. Acta Sedimentologica Sinica. 2007. 25(3): 401-408 (in Chinese)

Song J G and Wu Z Q. Some considerations on the Silurian petroleum exploration in the Tarim Basin - taking the Tazhong region as an example. Petroleum Exploration and Development. 2004. 31(5): 127-129 (in Chinese)

Song W J, Li Y J, Wang G L, et al. Sedimento-tectonic setting of the Silurian-Devonian clastic rocks in the central Tarim Basin, NW China. Chinese Journal of Geology. 2003. 38(4): 519-528 (in Chinese)

Wang G W and Zhang X P. Well logging sedimentary facies of the Silurian in the Tazhong area of the Tarim Basin. Journal of China University of Petroleum. 2006. 30(3): 40-45 (in Chinese)

William A A, Tim F W, Khaled F, et al. Neogene tectonic, stratigraphic, and play framework of the southern Laguna Madre-Tuxpan continental shelf, Gulf of Mexico. AAPG Bulletin. 2005. 89(6): 725751

$\mathrm{Xu}$ X H. Formation of paleo-uplift and petroleum occurrence in the Tarim Basin. Journal of Tongji University. 2004. 32(4): 461-465 (in Chinese)

Zhang G Y, Wang H J and Li H H. Main controlling factors of the oil and gas reservoirs and petroleum distribution in the craton zone of the Tarim Basin, northwest China. Chinese Science Bulletin. 2002. 47(S1): 24-29 (in Chinese)

Zhang $\mathrm{J}$ L and Zhang Z J. Sedimentary facies of the Silurian tidedominated paleo-estuary of the Tazhong area in the Tarim Basin. Petroleum Science. 2008. 5(2): 95-104

Zhou X Y, Yang H J, Cai Z Z, et al. Cases of discovery and exploration of marine fields in China (Part 10): The Hadexun sandstone oilfield in Tarim Basin. Marine Origin Petroleum Geology. 2007. 27(4): 5160 (in Chinese)

Zhu X M, Wang G W and Xie Q B. Characteristics and distribution of depositional systems of Silurian in Tarim Basin. Journal of the University of Petroleum, China. 2002. 26(3): 5-11 (in Chinese)

(Edited by Hao Jie) 